\title{
DISTRIBUTION, ADAPTATION AND PROBABLE ORIGIN OF AN ALL-FEMALE FORM OF POECILIOPSIS (PISCES: POECILIIDAE) IN NORTHWESTERN MEXICO ${ }^{1}$
}

\author{
William S. Moore, Robert Rush Miller, ${ }^{2}$ and R. Jack Schultz \\ Biological Sciences Group, University of Connecticut and Museum of Zoology, \\ University of Michigan
}

Received March 18, 1970

At least five, morphologically distinct, all-female forms occur in the viviparous fish genus Poeciliopsis (Schultz, 1966; Schultz, 1969). These appear to have had a similar origin, even though in different parts of their range they are not associated with the same gonochoristic (bisexual) species of Poeciliopsis. Morphological and experimental evidence indicate that the common ancestor to all of the unisexual forms was a diploid unisexual that originated through hybridization, at which time it was endowed with its obligatory unisexuality and a disruptive meiotic mechanism. This form, termed $P$. monacha-lucida (Schultz, 1969) has given rise to two gynogenetic triploid populations by incorporating an additional genome from one or the other of the ancestral bisexual species involved in its origin. Two other derived forms are diploid and like $P$. monacha-lucida sustain themselves by a unique reproductive mechanism termed hybridogenesis (Schultz, 1969).

In gynogenesis, spermatozoa are required to initiate cleavage, but paternal chromatin is not incorporated into the zygotic nucleus. Offspring of hybridogenetic organisms, on the other hand, exhibit characteristics of both parents but unisexuality is retained by excluding the entire paternal genome from functional ova in the process of oogenesis. The latter mode of reproduction, theoretically, has high adaptive value. Females that reproduce by such a mechanism have a genome which is isolated from the gene pool of the bisexual species

\footnotetext{
${ }^{1}$ Supported by NSF grants \# GB7738, G-24129, GB4306 and GB-6272X.

2 University of Michigan.
}

Evolution 24:789-795. December, 1970 that serves as its sexual host. However, since progeny carry the paternal genome, one would expect them to be at least partially adapted to the specific habitat of the host species and at the same time have a higher reproductive potential because of their obligatory all-femaleness. In addition, such organisms are in essence always $F_{1}$ hybrids and display, at least in the laboratory, a certain amount of "hybrid vigor."

The northernmost species of the genus is Poeciliopsis occidentalis (Baird and Girard) which ranges from southern Arizona along the Pacific coastal drainages of Sonora, Mexico, to the Rio Mayo. P. lucida Miller, a closely related species, occupies the next three river systems to the south: the Rios Fuerte, Sinaloa and Mocorito (Miller, 1960). Both species are associated with a hybridogenetic all-female form.

The unusual biology of these animals presents certain taxonomic problems. The hybridogenetic female associated with $P$. lucida was originally designated $\mathrm{Cx}$ (Schultz, 1961). Since it now appears that $\mathrm{Cx}$ arose through hybridization of $P$. lucida and a distantly related species, $P$. monacha Miller, emphasis on the origin should be maintained and the name $P$. monacha-lucida recently has been adopted (Schultz, 1969). Morphological data indicate that the "isolated" hybridogenetic genome is primarily a $P$. monacha genome and by virtue of this reproductive mechanism its inheritance is clonal. Since these females normally mate with $P$. lucida males the "excluded" genome is entirely a $P$. lucida derivative. The first all-female form discovered in the genus was designated Fx and its bisexual "host" species F (Miller and Schultz, 1959; Schultz, 
1961). F is similar to $P$. occidentalis and if the two differ at all it would be conservative to say they have diverged no further than the subspecies level: we adopt the usage of $P$. occidentalis in preference to $\mathrm{F}$.

Schultz (1969) believed that the hybridogenetic $\mathrm{Fx}$ arose from $P$. monacha-lucida which migrated into the range of $P$. occidentalis where the role of $P$. lucida males was adopted by the closely related $P$. occidentalis. It is also possible that $\mathrm{Fx}$ was derived from hybridization between occidentalis and monacha assuming that monacha once lived or still lives north of its present known range. In either case, the result would be retention of the primarily monacha "isolated" genome with inclusion and exclusion of a paternally derived $P$. occidentalis genome in each generation. To be consistent with the $P$. monacha-lucida designation this form should be called $P$. monacha-occidentalis.

Evidence documented by Ohno et al. (1968) indicates that mechanisms leading to gene duplication have been significant in vertebrate evolution. Polyploidizations appear to have occurred at the base of the incipient vertebrate phylogeny and subsequently at several critical points in the evolution of aquatic vertebrates up to the emergence of terrestrial forms. An examination of living unisexual vertebrate "species" reveals a pattern of hybridization leading to unisexuality and triploidy. This prompted Schultz (1969) to postulate that a tetraploid species could be formed through populations similar to Poeciliopsis. The series of events leading to the existing triploid forms is thought to have involved the formation of a hybridogenetic diploid ovum which was fertilized; the resulting triploid offspring then achieved fixation in the population. The hypothesized route to the formation of a tetraploid would require incorporation of a paternally derived genome into a triploid ovum resulting in a tetraploid zygote which subsequently achieved fixation. Implicit is the assumption that both the unisexual diploid and triploid forms are capable of sustaining themselves in sufficient numbers and for a long enough period of time to allow for the occurrence of a series of rare events.

The purposes of this paper are: (1) To report the geographical distribution of the hybridogenetic diploid unisexual, $P$. monacha-occidentalis, in relation to its "host" species; (2) to use these data to gain a better understanding of the origin of this form and factors important to its distribution; (3) to determine the "fitness" of the unisexual form relative to $P$. occidentalis and to postulate the existence of stability in this complex over a considerable length of time.

\section{Materials and Methods}

Forty-seven collections preserved at the University of Michigan Museum of Zoology (UMMZ) were examined, representing material collected over the range of $P$. occidentalis (sensu lato) from 1936 to 1969. On close examination, the females of $P$. monacha-occidentalis and $P$. occidentalis can be distinguished on morphological bases (Miller and Schultz, 1959, and Schultz, 1961). All collections containing ten or more specimens were sorted and mature females of each type were counted. Males and fish less than $20 \mathrm{~mm}$ in total length were not included in calculating population composition.

\section{Results}

The greatest concentration of $P$. monacha-occidentalis was found in the southernmost drainage, the Rio Mayo (Fig. 1), where in one collection the female population consisted of $97 \%$ unisexuals. North of the Rio Mayo, the next three river systems had a lower percentage of $P$. monacha-occidentalis. A maximum $P$. monacha-occidentalis level of $38 \%$ was found in the Rio Yaqui, 11\% in the Rio Matape and 30\% in the Rio Sonora. Each drainage has an area of maximum $P$. monacha-occidentalis concentration which declines both up- and downstream. The known northern limit of $P$. monacha-occidentalis is in the Rio de la Concepcion drainage where a peak $P$. mo- 


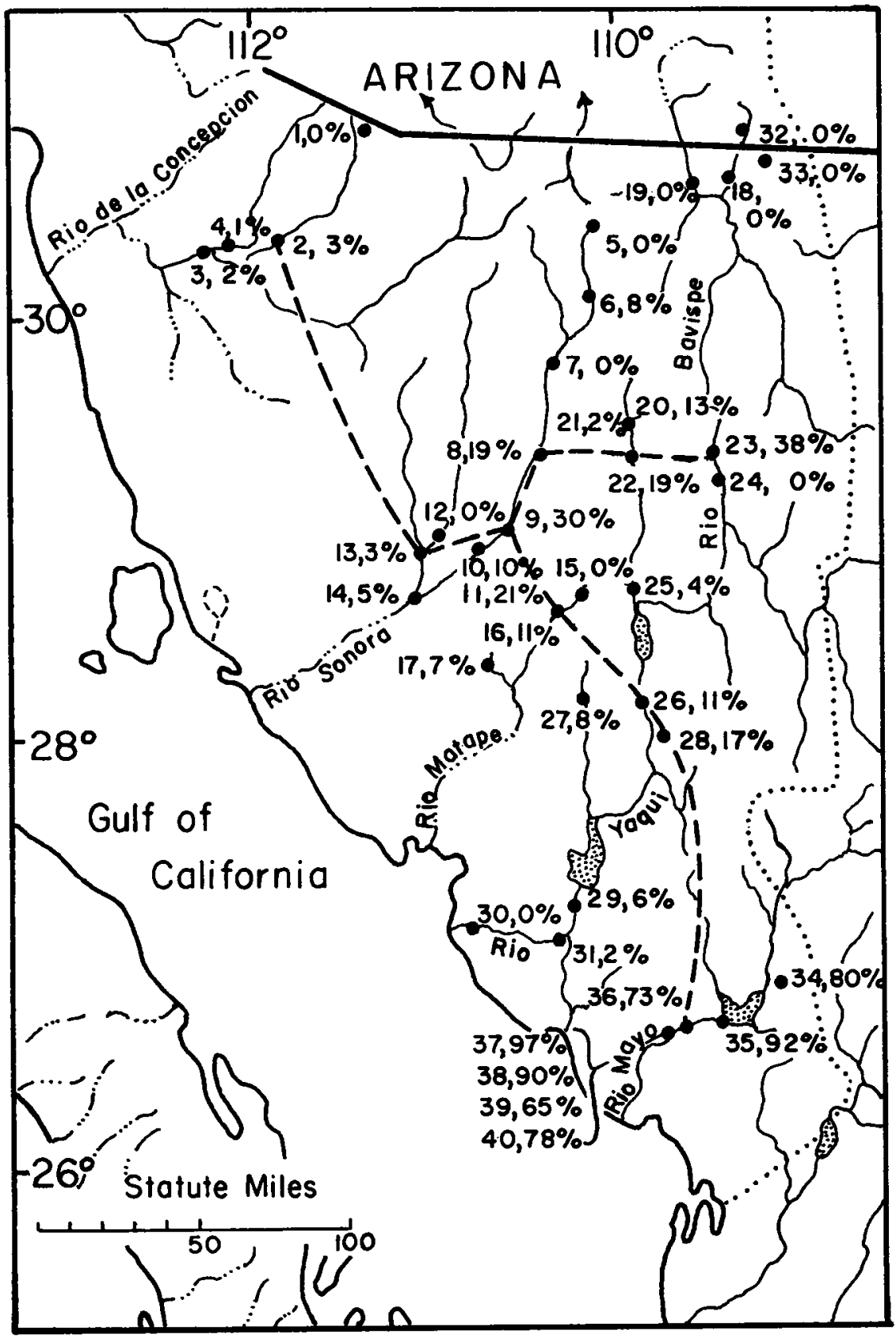

FIG. 1. Distribution of the all-female form $P$. monacha-occidentalis over the range of its host species $P$. occidentalis in Sonora, Mexico. The number of the collection site is given along with the percentage of females in the population that consist of $P$. monacha-occidentalis. The dashed line: indicates the trend in maximum $P$. monacha-occidentalis concentration in each drainage. 
TABLE 1. Proportion of mature females of the bisexual species Poeciliopsis occidentalis to females of the unisexual form $\mathrm{P}$. monacha-occidentalis.

\begin{tabular}{|c|c|c|c|c|c|c|c|}
\hline \multirow[b]{2}{*}{ Drainage } & \multirow[b]{2}{*}{ Site } & \multicolumn{2}{|c|}{ Location } & \multirow[b]{2}{*}{ Date } & \multicolumn{2}{|c|}{ Number of females } & \multirow{2}{*}{$\begin{array}{c}\text { Percent } \\
\text { Unisexual }\end{array}$} \\
\hline & & $\mathbf{N}$ & $\mathbf{W}$ & & Bisexual & Unisexual & \\
\hline & 1 & $31^{\circ} 15$ & $111^{\circ} 15$ & $6 / 16 / 55$ & 83 & 0 & $0 \%$ \\
\hline Rio de la & 2 & $30^{\circ} 45$ & $111^{\circ} 45$ & $4 / 9 / 41$ & 1838 & 63 & $3 \%$ \\
\hline \multirow{6}{*}{ Concepcion } & 3 & $30^{\circ} 42$ & $112^{\circ} 08$ & $2 / 9 / 50$ & 184 & 3 & $2 \%$ \\
\hline & 4 & $30^{\circ} 41$ & $112^{\circ} 05$ & $3 / 9 / 41$ & 165 & 2 & $1 \%$ \\
\hline & 5 & $30^{\circ} 58$ & $110^{\circ} 05$ & $4 / 6 / 55$ & 83 & 0 & $0 \%$ \\
\hline & 6 & $30^{\circ} 38$ & $109^{\circ} 57$ & $3 / 10 / 41$ & 136 & 11 & $8 \%$ \\
\hline & 7 & $30^{\circ} 15$ & $110^{\circ} 13$ & $3 / 11 / 41$ & 322 & 0 & $0 \%$ \\
\hline & 8 & $29^{\circ} 43$ & $110^{\circ} 12$ & $3 / 11 / 41$ & 86 & 20 & $19 \%$ \\
\hline \multirow[t]{7}{*}{ Rio Sonora } & 9 & $29^{\circ} 25$ & $110^{\circ} 25$ & $1 / 26 / 51$ & 76 & 32 & $30 \%$ \\
\hline & 10 & $29^{\circ} 20$ & $110^{\circ} 31$ & $1 / 26 / 51$ & 45 & 5 & $10 \%$ \\
\hline & 11 & $29^{\circ} 20$ & $110^{\circ} 31$ & $1 / 30 / 55$ & 167 & 43 & $21 \%$ \\
\hline & 12 & $29^{\circ} 20$ & $110^{\circ} 50$ & $3 / 12 / 40$ & 17 & 0 & $0 \%$ \\
\hline & 13 & $29^{\circ} 10$ & $110^{\circ} 55$ & $1 / 27 / 51$ & 31 & 1 & $3 \%$ \\
\hline & 14 & $29^{\circ} 04$ & $110^{\circ} 54$ & $3 / 11 / 40$ & 38 & 2 & $5 \%$ \\
\hline & 15 & $29^{\circ} 09$ & $109^{\circ} 15$ & $3 / 17 / 41$ & 55 & 0 & $0 \%$ \\
\hline \multirow[t]{9}{*}{ Rio Matape } & 16 & $29^{\circ} 00$ & $110^{\circ} 07$ & $3 / 18 / 41$ & 954 & 122 & $11 \%$ \\
\hline & 17 & $28^{\circ} 44$ & $110^{\circ} 20$ & $3 / 28 / 59$ & 302 & 22 & $7 \%$ \\
\hline & 18 & $31^{\circ} 10$ & $109^{\circ} 15$ & $4 / 8 / 44$ & 34 & 0 & $0 \%$ \\
\hline & 19 & $31^{\circ} 07$ & $109^{\circ} 34$ & $1 / 22 / 51$ & 41 & 0 & $0 \%$ \\
\hline & 20 & $30^{\circ} 03$ & $109^{\circ} 48$ & $6 / 1 / 36$ & 130 & 20 & $13 \%$ \\
\hline & 21 & $29^{\circ} 59$ & $109^{\circ} 48$ & $1 / 25 / 51$ & 161 & 3 & $2 \%$ \\
\hline & 22 & $29^{\circ} 49$ & $109^{\circ} 44$ & $3 / 15 / 41$ & 74 & 17 & $19 \%$ \\
\hline & 23 & $20^{\circ} 47$ & $109^{\circ} 18$ & $3 / 14 / 41$ & 97 & 60 & $38 \%$ \\
\hline & 24 & $29^{\circ} 46$ & $109^{\circ} 18$ & $3 / 13 / 41$ & 22 & 0 & $0 \%$ \\
\hline \multirow[t]{12}{*}{ Rio Yaqui } & 25 & $29^{\circ} 16$ & $109^{\circ} 44$ & $3 / 16 / 41$ & 179 & 8 & $4 \%$ \\
\hline & 26 & $28^{\circ} 47$ & $109^{\circ} 31$ & $3 / 19 / 41$ & 17 & 2 & $11 \%$ \\
\hline & 27 & $28^{\circ} 37$ & $109^{\circ} 57$ & $3 / 28 / 59$ & 286 & 25 & $8 \%$ \\
\hline & 28 & $28^{\circ} 35$ & $109^{\circ} 30$ & $5 / 5 / 45$ & 81 & 17 & $17 \%$ \\
\hline & 29 & $27^{\circ} 45$ & $109^{\circ} 50$ & $1 / 25 / 50$ & 100 & 6 & $6 \%$ \\
\hline & 30 & $27^{\circ} 40$ & $110^{\circ} 25$ & $2 / 1 / 55$ & 24 & 0 & $0 \%$ \\
\hline & 31 & $27^{\circ} 35$ & $110^{\circ} 00$ & $1 / 28 / 51$ & 86 & 2 & $2 \%$ \\
\hline & 32 & $31^{\circ} 20$ & $109^{\circ} 20$ & $1 / 27 / 50$ & 535 & 0 & $0 \%$ \\
\hline & 33 & $31^{\circ} 13$ & $109^{\circ} 10$ & $7 / 15 / 55$ & 96 & 0 & $0 \%$ \\
\hline & 34 & $27^{\circ} 25$ & $109^{\circ} 10$ & $2 / 16 / 57$ & 158 & 665 & $80 \%$ \\
\hline & 35 & $27^{\circ} 10$ & $108^{\circ} 50$ & $3 / 21 / 41$ & 3 & 33 & $92 \%$ \\
\hline & 36 & $27^{\circ} 05$ & $109^{\circ} 30$ & $3 / 14 / 40$ & 3 & 8 & $73 \%$ \\
\hline \multirow[t]{4}{*}{ Rio Mayo } & 37 & $27^{\circ} 05$ & $109^{\circ} 30$ & $2 / 25 / 55$ & 9 & 321 & $97 \%$ \\
\hline & 38 & $27^{\circ} 05$ & $109^{\circ} 30$ & $3 / 27 / 59$ & 10 & 94 & $90 \%$ \\
\hline & 39 & $27^{\circ} 05$ & $109^{\circ} 30$ & $4 / 16 / 68$ & 49 & 92 & $65 \%$ \\
\hline & 40 & $27^{\circ} 05$ & $109^{\circ} 30$ & $11 / 4 / 69$ & 17 & 59 & $78 \%$ \\
\hline
\end{tabular}

nacha-occidentalis concentration of only $3 \%$ was observed. This value is considerably lower than the maximum values found in the four more southerly drainages. Over 1000 specimens of $P$. occidentalis from scattered locations in the Gila River system have been examined with no evidence of the aberrant dentition characteristic of all- female forms. It appears that $P$. monachaoccidentalis has never successfully colonized this system, although $P$. occidentalis has occurred there in great abundance until recently (Hubbs and Miller, 1941; Minckley and Deacon, 1968).

The collections examined were made over a period of 33 years. Two locations are 
represented by repeat collections made in different years. In the Rio Sonora two collections (10 and 11 ) were made at the same location in 1951 and 1955 respectively. In 1951, the female population contained $10 \%$ P. monacha-occidentalis and in 1955, 21\%. In the Rio Mayo five collections were taken near Navojoa. Four of these $(37,38,39$ and 40) were from precisely the same location while the fifth (36) was taken slightly to the east. The $P$. monacha-occidentalis composition of these collections was $97 \%, 90 \%, 65 \%, 78 \%$ and $73 \%$ respectively. The mean composition was $80.6 \%$.

\section{Discussion}

Hoy (1943) described two distinct physiographic regions in Sonora, Mexico. The Sonoran Desert forms a narrow band along the Gulf of California from 50-100 miles wide. To the east this gives way abruptly to the Sierra Madre Occidental, the highest mountain range in the country.

The unisexual form, $P$. monacha-occidentalis, is restricted to a narrow coastal piedmont between the two regions. To the west the ranges of both $P$. occidentalis and $P$. monacha-occidentalis are limited by the Sonoran Desert. However, this region appears to be less hospitable to $P$. monachaoccidentalis than to $P$. occidentalis since the proportion of the unisexual form diminishes in the desert. A collection (30) taken within 15 miles of the coast contained $P$. occidentalis but no unisexuals.

To the east of the Sonoran Desert a discernible gradient occurs in the populations with the proportion of $P$. monacha-occidentalis increasing on the coastal piedmont to a region of maximum unisexual composition indicated by the dashed line in Figure 1. The eastward extension of both forms is cut off by the rising Sierra Madre Occidental. Between the regions of maximum unisexual composition and the eastern extent of the range the variations in composition appear to be related more to local habitat differences than to physiography.

To the north $P$. occidentalis extends to the United States border in the headwaters of the Rios Yaqui, Sonora and Concepcion. It also occurs in the Gila River basin of southern Arizona. The most northern collections of $P$. monacha-occidentalis are in the Rio Concepcion (2) and the Rio Sonora (6) south of $30^{\circ} 45^{\prime} \mathrm{N}$. The percentage of $P$. monacha-occidentalis in these collections was small.

The southern limit of both forms is the Rio Mayo which is delimited from the northern range of $P$. lucida in the Rio Fuerte by a distance of over 80 miles in the lowlands and a high mountain ridge in the headwaters.

The distribution of $P$. monacha-occidentalis cannot be explained on the basis of physiography alone. In addition to the general trends outlined above, considerable local variation occurs, particularly in the upper reaches of the Rios Sonora and Yaqui. Three collections in the Rio Sonora were taken within a period of 2 days; yet the most southern collection (8) contained $19 \%$ P. monacha-occidentalis females, the middle collection (7) $0 \%$, and the more northern collection (6), $8 \%$. An even sharper contrast in the proportion of $P$. monacha-occidentalis occurred in the Rio Bavispe, a northern tributary of the Yaqui, where two collections (23 and 24) taken on successive days only 3 miles apart contained $38 \%$ and $0 \%$ unisexuals.

The argument that $P$. monacha-occidentalis arose through displacement of the $P$. lucida genome from the hybridogenetic $P$. monacha-lucida by a $P$. occidentalis genome is based on three facts: (1) Experimental evidence that the hybridogenetic females are capable of this transition (Schultz, 1961, 1966). (2) No other species has been found in the range of $P$. occidentalis that has the potential to form an indigenous hybridogenetic female (Schultz, 1969). (3) Direct hybridization of $P$. occidentalis with $P$. monacha imposes too many difficulties. Among these difficulties is the problem that the closest known locality of $P$. monacha is the headwaters of the Rio Fuerte. In order for an individual to reach $P$. occidentalis 
territory it would have to travel about 200 miles of inhospitable waters; $P$. monachalucida, on the other hand, is abundant throughout most of the Fuerte, including the lower reaches. Although it is possible that an undiscovered pocket of $P$. monacha exists in an uncollected headwater of one of the $P$. occidentalis rivers, one would expect that the extensive collections from this region would include a few strays; but they have not.

It is evident that $P$. monacha-occidentalis is neither ubiquitous nor homogenous in its distribution over the range of $P$. occidentalis and furthermore, it seems likely that although $P$. monacha-occidentalis has ecological requirements similar to $P$. occidentalis, they are not identical. If $P$. monachaoccidentalis has arisen as suggested, one would expect it to be most successful in an environment intermediate between that of the parental species involved in the hybridogenetic origin (i.e. $P$. lucida and $P$. monacha) and $P$. occidentalis. This appears to be true since at Navojoa, which is only 80 miles from the northern extent of $P$. monacha-lucida and the limited range of $P$. monacha, the proportion of $P$. monacha-occidentalis ran as high as $97 \%$, whereas at its northern limit it constituted only 1-8\% of the female population. With the addition of the fact that collections taken in the lower regions of the Rio Yaqui in the Sonoran Desert, a short distance from Navojoa, contain 0-6\% P. monacha-occidentalis, it follows that the overall distribution can best be explained by differences in ecological requirements of $P$. monacha-occidentalis and $P$. occidentalis.

Substantial fluctuation in year-to-year composition of female populations is also evident. Nonetheless, the physiography of the area and distribution of $P$. monachaoccidentalis again imply that proportional regulation occurs within a river drainage. The five river systems that support these populations are separated not only by considerable distance but by mountain ridges which preclude migration via flooding in the headwaters or stream capture. Although
Poeciliopsis exhibits high salinity tolerances, inter-drainage migration is probably limited. Leaving the preferred habitat of the piedmont, crossing the Sonoran Desert, moving up the coast, crossing the desert again and going onto the piedmont in another drainage is probably an infrequent occurrence. It appears that $P$. monachaoccidentalis populations are sustained without extensive recruitment via migration.

The nature of local population regulation in this "sexual-parasite-host" interaction is not clear. Since the all-female form relies on P. occidentalis for sperm, competitive exclusion of the latter would bring about the demise of the former. Why this has not occurred, particularly in the Rio Mayo where the all-female $P$. monacha-occidentalis is so abundant, is not evident from these data. However, the sequence of collections taken at Navojoa, spanning over 29 years (approximately 80-135 generations) suggests localized proportional regulation does occur within rather broad limits. For the time being the nature of this regulation must remain an enigma. Although extensive field and experimental studies are needed to understand the population ecology of this complex, the occurrence of $P$. monacha-occidentalis in high proportions and the fact that the complex has existed at least since 1936 attest to the high adaptive value of the hybridogenetic mechanism.

\section{SUMMARY}

The distribution of the all-female "species" $P$. monacha-occidentalis over the range of its "host species" $P$. occidentalis is presented. The all-female form achieves greatest concentration at the southern limit of its range in the Rio Mayo and is successively diminished in the four northerly drainages. Within a given drainage the proportion of $P$. monacha-occidentalis increases from very low levels at its western extent, along the eastern edge of the Sonoran Desert, to maximum levels midway between the eastern and western boundaries 
of its range. To the east of this maximum, considerable localized fluctuation in proportional levels of $P$. monacha-occidentalis occurs.

The hypothesis which most parsimoniously explains the origin and distribution of the unisexual form, $P$. monacha-occidentalis, is:

1) $P$. monacha-occidentalis arose from $P$. monacha-lucida, a unisexual form of a more southern origin which has migrated north into the range of $P$. occidentalis.

2) It sustains itself by mating with males of the indigenous $P$. occidentalis. In so doing, it inherits not only some of its morphological characters but also some of its ecological requirements. All-femaleness and the maternal genome are retained, however, via hybridogenesis.

3) The level at which $P$. monacha-occidentalis females are found in a population is probably determined by the slight differences in niche requirements of $P$. monachaoccidentalis and the host species $P$. occidentalis.

A stable equilibrium between the two forms appears to exist within a given drainage and possibly within local populations. However, the causative factors in this equilibrium cannot be resolved from these data.

\section{Acknowledgment}

We thank Miss Mary M. Hubbard for preparing Figure 1.

\section{Literature Cited}

Hoy, H. E. 1943. A new map of the surface configuration of Mexico. Papers Michigan Acad. Sci. 28:441-443.

HubBs, C. L., AND R. R. MIIIER. 1941. Studies of the fishes of the order Cyrinodontes XVII. Genera and species of the Colorado River system. Occ. Papers Mus. Zool. Univ. Michigan, No. 433:1-9.

MIILER, R. R. 1960 . Four new species of viviparous fishes, genus Poeciliopsis, from northwestern Mexico. Occ. Papers Mus. Zool. Univ. Michigan, No. 619:1-11.

Mitler, R. R., AND R. J. Schultz. 1959. Allfemale strains of the teleost fishes of the genus Poeciliopsis. Science 130:1656-1657.

Minckley, W. L., and J. E. Dracon. 1968. Southwestern fishes and the enigma of endangered species. Science 159:1424-1432.

Orno, S., V. Wolf, and N. B. Atrin. 1968. Evolution from fish to mammals by gene duplication. Hereditas 59:169-187.

ScHuLTz, R. J. 1961. Reproductive mechanism of unisexual and bisexual strains of the viviparous fish Poeciliopsis. Evolution 15:302-325.

- 1966. Hybridization experiments with an all-female fish of the genus Poeciliopsis. Biol. Bull. 130:415-429.

- 1969. Hybridization, unisexuality and polyploidy in the teleost Poeciliopsis (Poeciliidae) and other vertebrates. Amer. Natur. 103: 605-619. 